\title{
Students' Mathematical Communication Skills in Solving STEM Problems
}

\author{
Nita Ardianti ${ }^{1, *}$ Tri Atmojo Kusmayadi ${ }^{2}$ Laila Fitriana ${ }^{3}$ \\ ${ }^{1}$ Postgraduate of Mathematis Education, Faculty of Teacher Training and Education, Universitas Sebelas \\ Maret, Indonesia \\ ${ }^{2}$ Faculty of Mathematics and Natural Sciences, Universitas Sebelas Maret, Indonesia \\ ${ }^{3}$ Faculty of Teacher Training and Education, Universitas Sebelas Maret, Indonesia \\ *Corresponding author. Email: nitaardianti.anw@student.uns.ac.id
}

\begin{abstract}
STEM is seen as an essential means of realizing informed citizens who benefit from national, regional, and local policies decisions. This study reveals how the categories of students' mathematical communication in solving STEM problems on the material of the two-variable system of linear equations (SPLDV). Mathematical communication express mathematical ideas with symbols, tables, or other forms in mathematical language. The qualitative research took students of SMP Negeri 2 Belitang III, Indonesia and with 20 subjects. The data were collected through tests and interviews, then they were analyzed through the stages of data reduction, data presentation, and drawing conclusions. Instrument validation to obtain the validity of data. The results showed three categories of mathematical communication, namely symbolic, visual, and text communication, in solving STEM problems. Symbolic problem-solvers have the characteristics of students who can express real situations given in language or mathematical symbols. Meanwhile, visual problem-solvers tend to express the situation of mathematical ideas in the form of graphs, tables, or other forms. As for textual students, it is easier to express situations into mathematical language or symbols. Future research can focus on students' mathematical communication characteristics from the timing aspect, which highlights when problem-solvers communication skills emerge in solving problems.
\end{abstract}

Keywords: Mathematical communication, Problem-solving, STEM, Two-variable linear equation systems (SPLDV).

\section{INTRODUCTION}

The growth of the times today in the development of technology and science demands something new in education. STEM is seen as an essential means of realizing informed citizens who benefit from national, regional, and local policy decisions [1]. STEM is learning that integrates two or more disciplines. STEM-based education is an interdisciplinary field that connects four disciplines: science, technology, engineering, and mathematics [2].

Communication is an event that conveys information/messages or ideas to each other in a community [3]. Mathematical communication is the skills in expressing mathematical ideas with symbols, tables, diagrams, or other forms in clarifying mathematical problems and delivered using mathematical language [4]. Through communication, the ideas conveyed can be communicated either in writing or verbally [5]. Mathematical communication is one of the essential basic skills, so students need to have it in the standard of the mathematics learning process [6]. The reasons for the importance of mathematical communication in learning: a) through the communication of mathematical ideas that can be found from various perspectives, b) can sharpen the way of thinking to increase the ability to see the relationship between mathematical content, c) can measure various mathematical understandings, d) organize thinking processes, e) construct knowledge in learning mathematics, develop problem-solving, improve reasoning, foster self-confidence, and improve social skills, and f) develop critical, rational thinking, and social skills through writing and talking. [7].

Communication in mathematics for the junior secondary level is measured from three aspects: 1) written text is to answer an image or model problem in mathematical form based on their language, 2) drawing is to reflect pictures, graphs, diagrams, and 
other forms into the form of mathematical ideas or vice versa, and 3) mathematical expressions are to express situations, pictures, or natural objects into mathematical language or symbols [8]. In this study, mathematical communication is defined as the ability to reflect images, tables, graphs into mathematical ideas with mathematical concepts or situations using their language in writing mathematically and correctly and expressing everyday events in language or mathematical symbols.

Various previous studies examined STEM, namely learning from STEM education to teach mathematics and mathematics curriculum developed through STEM-based activities [9][10]. The existence of previous research that examines STEM shows that STEM has a positive influence on the learning process and solving mathematical problems. Relevant research on mathematical communication is the teaching approach in developing mathematical communication [11], the effectiveness of mathematical communication [12]. Based on research that examines mathematical communication shows that mathematical communication becomes vital in communication problems in solutions. Based on the literature review, a gap needs to be investigated, namely how students' mathematical communication is based on STEM problems.

This research aimed to reveal how the categories of student communication in solving STEM problems. This research needs to be conducted because the research process aims to find out mathematical communication in solving STEM problems. Suppose there is no research exploring mathematical communication in solving problems related to STEM aspects in education. In that case, the level of student communication related to STEM aspects cannot be known. Thus, mathematical communication in solving STEM problems cannot be increased because there is no effort to improve their communication skills. After all, mathematical communication is one of the abilities that every student must have, and STEM is essential in education.

\section{METHODS}

\subsection{Research Design}

This research used qualitative descriptive research. Qualitative research uses a post-positivistic paradigm to obtain in-depth description, understanding, and interpretation [13]. The data also are the mathematical communication ability of students in solving STEM problems.

\subsection{Participants}

Participants are junior high school (SMP) students in the South Sumatra region, especially in the Belitang III section. Subjects came from class IX SMP Negeri 2 Belitang III taken by purposive sampling technique. Subjects are participants who have received material on a two-variable linear equation system (SPLDV) and have communication skills in solving problems. The number of subjects in this study was twenty students. Then, the subjects described in the article were three people whose data represented all the data. The distribution of subjects based on the results of the analysis carried out in the categorization of mathematical communication can be presented in Table 1.

Table 1. Subject distribution

\begin{tabular}{|l|l|}
\hline Category & Total \\
\hline Symbolic subject & 8 \\
\hline Visual subject & 8 \\
\hline Textual subject & 4 \\
\hline Total & 20 \\
\hline
\end{tabular}

\subsection{Instruments}

The instruments used in this study were communication skills tests and interview guidelines. Three validators validated the instrument. They are mathematicians and education experts as validators who provide suggestions to improve the quality of the instrument to be used. The test instrument used was a description test with a topic that contains indicators of mathematical communication in solving STEM problems. The validator suggested that the instrument used already represents all aspects of measuring mathematical communication skills in STEM problems. The three questions were given with the material of a system of linear equations with variables in descriptions.

\subsection{Data Collection Method}

This research used tests and interview guidelines as data collection method. Subjects were given a test of mathematical communication skills. The tests were used to determine students' mathematical communication skills in solving mathematical problems related to STEM. The following is a mathematical communication ability test instrument tested on the subject as Figure 1. 


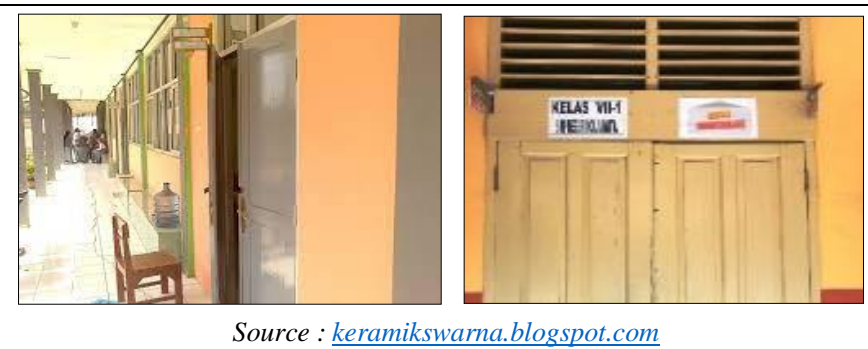

Mr Arthur as the principal at SMP Negeri 2 Belitang III, ordered a handyman to repair the damaged school door. Before starting to repair, the craftsman bought four nails and one screw for Rp. 5,500. After repairing it, it turned out that the repairman still needed nails and screws, so he bought another six nails and three screws for Rp. 8,400.00. Determine the form of the two-variable system of linear equations in the story!

Using the graphical method, determine the solution set of the system of equations $3 x+2 y=18$ and $3 x+$ $6 y=30$, with $x$ and $y$ where the solution variable is on the set of real numbers!

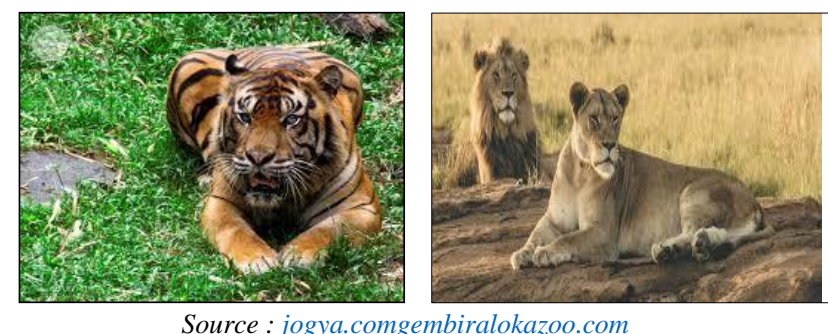

Gembiraloka Zoo is one of the zoos in Central Java. Inside the zoo, there are various kinds of animals, including Sumatran tigers and lions. Every morning, the zoo staff gives food rations in the form of chicken meat for the tigers and lions to eat. The ratio given for two tigers and three lions is twenty chickens. One morning, a tiger from another Java regional zoo was transferred to the Gembiraloka Zoo, prompting the zoo staff to add twentyfour chickens. Determine the amount of chicken the zookeeper gave for a tiger and a lion!

Figure 1 STEM problem of mathematical communication System of Linear Equations Two Variables.

\subsection{Data Analysis}

The stages of data analysis in this study are reduction, presentation, and conclusion drawing [14]. The reduction stage was carried out to select the essential data needed to achieve the research objectives. The results of the data obtained were reduced to be presented in describing mathematical communication data based on several categories. Furthermore, the researcher drew conclusions from the results of the data obtained to answer the study's objectives. The validity of the data was carried out by implementing the triangulation method; the researcher compares the data obtained from the results of tests, interviews, observations, and documentation.

\section{FINDING}

Based on the results of the tests given to students, the researcher described data from one subject based on categories following mathematical communication abilities. There are three categories of student communication in solving STEM problems. The data exposure is presented as follows.

\subsection{Category 1: symbolic communication}

Figure 2 is the student answer sheet with the first type of mathematical communication, namely symbolic communication. Eight students can solve problems related to technology, and engineering 
aspects that are given well based on the given situation can create a two-variable linear equation system. Students write a system of two-variable linear equations well based on real situations or objects in language or mathematical symbols.

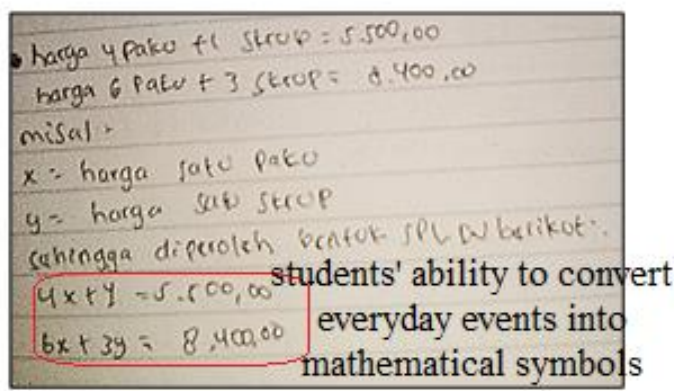

Figure 2 One of the results of students' answers in the symbolic communication category.

This is confirmed by student statements in the interview excerpts, as follows:

$$
\begin{array}{r}
\text { Researcher } \quad \text { "How do you read, understand and } \\
\text { explain the story? }
\end{array}
$$

Student : : In the question asked the form of a system of linear equations with two variables and it is known that the craftsman bought four nails and five screws for Rp. 5,500.00 and the craftsman bought six nails and three screws for Rp. 8,400.00."

Researcher : : How do you turn the story problem into mathematics?"

Student : "I symbolize by $x$ as the price of a nail, and y as the price of one screw."

Researcher : "Why do you use a mathematical symbol for that mathematical problem?"

Student

: "The reason I assume is to make it easier to work on the problem in determining the form of a twovariable linear equation system."

Researcher : "After getting information from the question, what do you do?"

Student : "Determine two equations, for the first equation is $4 x=y=5.500$ and for the second equation is $6 x+$ $3 y=8400$, so that from the two equations, it becomes a system of linear equations with two variables."

Based on the interviews, students work on problems that include aspects of technology and engineering in measuring mathematical communication on the material of a two-variable linear equation system. Students also can perform the steps in solving problems. This shows that before working, students understand the problem by obtaining the necessary information. So, to proceed to the next stage, students already have ideas that are used to solve problems, namely symbolizing each known price of goods to make it easier to determine the form of a system of equations. On the other hand, based on the answer sheets and the interviews, students solved the problems given in determining the form of a system of linear equations of two variables based on real situations or objects in mathematical form by using mathematical language or symbols. Students can state the situation given in language and mathematics because they first understand the questions given to write down information about what is known to be used as an example. Thus, students can create a system of equations based on the examples made. Based on interviews and answer sheets, the researcher can conclude that students can determine the form of equations of a two-variable linear equation system that includes aspects of technology and engineering in solving a problem well.

\subsection{Category 2: visual communication}

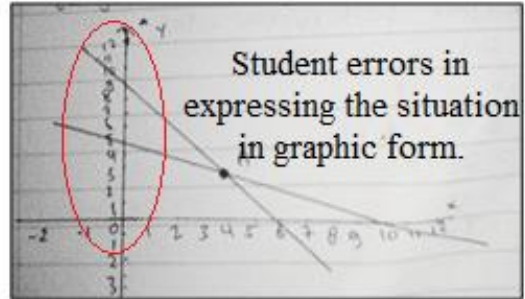

Figure 3 One of the results of students' answers in the visual category.

Students in the type two category of visual communication express mathematical ideas in graphs (see Figure 3) and solve problems that include aspects of mathematics in determining the set of solutions. There are eight students whose work results can visually describe mathematical ideas in the form of graphs. This is complemented by excerpts from the interviews, as follows:

Researcher : "What is the purpose of the questions you are going to do?"

Student : : "Determine the set of solutions using graphs."

Researcher : "What are the steps to solve the problem?" 
Student

\section{: "Find the point of intersection of the two equations. Each equation looks for the point of intersection on the $x$ - axis and from each equation then draws a graph.}

Based on the interviews that students work on problems that include mathematical aspects in measuring mathematical communication on the two linear equation material variables, students can solve problems. This shows that before making graphs of completion, students understand the stages that must be done first, namely by determining the intersection point of each equation to make appropriate and correct graphs. Moreover, based on the answer sheets and the interviews, students have not visualized the image well. The graphs made by the students' coordinate points are inconsistent, so that in making graphs, they do not get the complete set in the form of an exact cut point. However, indirectly students can visualize the given situation in solving the given problem in the form of a graph by determining the coordinate points made on the $x$ and $y$ coordinate axes that the graph passes. Based on interviews and answer sheets, the researcher can conclude that the students' explanations and completions in the interviews and the results of the answers are slightly different. This shows that students are not fully able to solve problems in making graphs.

\subsection{Category 3: text communication}

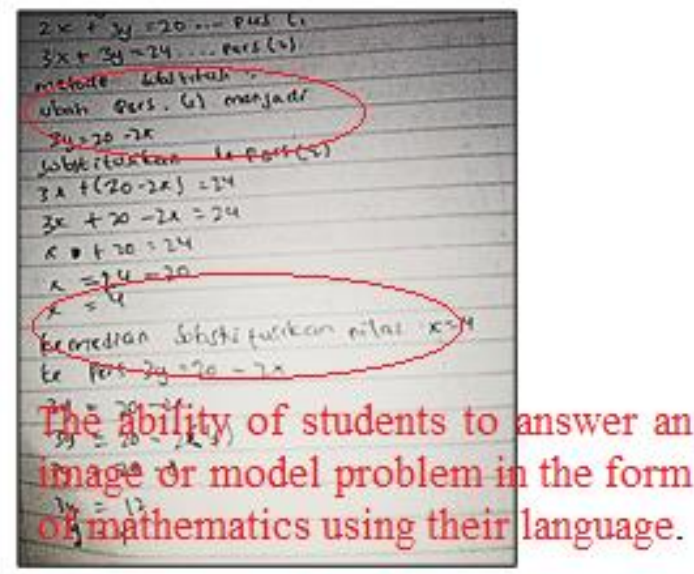

Figure 4 One of the results of student answers in the text communication category.

In addition to the two categories, there is a type 3 category of text communication: answering an image or model problem in mathematical form using their language. Four students can be categorized in the type of text communication. Based on the answers (Figure 4), category three students solve problems related to aspects of science by collecting crucial information contained in the questions and then changing the results of the information obtained into a system of two-variable linear equations. Essential information obtained based on the problems given must be scrutinized. If not, students will be wrong in determining the system of equations. The system of equations that students have formed is then calculated by substituting to get the value of $x$ and $y$. Accuracy in the work is essential to find the conclusion from the existing problems. After obtaining what they get, the first thing students do is to assume $x$ for the portion of chicken meat for a tiger and $y$ for the portion of chicken meat for a lion. Then, students create two equations based on the information obtained and their examples and change the equation $2 x+3 y=20$ to $3 y=20-2 x$, which then substitutes the modified equation into equation two to get the value of $x=4$. The next step that students take is to substitute the value of $x$ into equation 1 , which has been converted into $3 y=20-2 x$, to obtain the value of $y=4$. This is complemented by excerpts from the interviews, as follows:

Researcher : "Please explain how you found the answers obtained?"

Student : : "What I do is to read and look at the questions given. Then, I make an example, where $x$ is the portion of chicken meat given to a tiger and $y$ is the portion of chicken meat given to a lion. Based on the example, determine the system of linear equations that will be substituted between equation one which has been changed to equation two, so that the value of $y$ is obtained. Then, the obtained $x$ value is substituted into the equation containing the $x$ variable to get the $y$ value result. As a result of the substitution is executed by the value of $y=4$, so the result $x$ and $y$ values are the same."

Researcher : "What conclusions do you make based on the answers obtained?"

Student : "So a tiger and a lion each get 4 portions of chicken meat."

Based on the interviews that students have described in working on story problems in the science aspect to achieve communication indicators: answering a problem description or model in mathematical form using their language, and being able to understand questions based on the information obtained to solve problems using the substitution method in obtaining the value of an $\mathrm{x}$ and $\mathrm{y}$. So, 
students can make conclusions using their language appropriately. On the other hand, based on the answer sheets and results of the interviews, students answered a problem of an image or model in the form of mathematics using their language so that they were able to solve it by obtaining the correct conclusion. Students can interpret the steps in solving problems to answer the amount of chicken meat given by Gembiraloka zoo officials for a tiger and a lion using the substitution method correctly. Then, relate it to what is desired in the question using their language briefly. Based on interviews and answer sheets, the researcher can conclude that the explanations and completion of students in interviews and the answers can solve problems well. This shows that students can answer an image or model mathematical problem using their language based on the given mathematical situation.

\section{DISCUSSION}

Based on the results of the analysis that has been described, it can be said that the mathematical communication possessed by students has not fully met the measured mathematical communication indicators because there are indicators that have not been fully realized. Students belonging to the symbolic communication category can make mathematical models and a system of linear equations of two variables based on the given situation in questions related to technology and engineering aspects. When getting the answers obtained, students do not have difficulty in working on the questions. Students first understand the problem to obtain the information obtained to determine what is known so that students can make an example that is used to assume $\mathrm{x}$ as the price of one nail and $\mathrm{y}$ as the price of one screw. The existence of examples made by students makes it easier to determine mathematical models so that students can analyze and determine the system of linear equations of two variables correctly on each mathematical model of each price presented based on mathematical problems related to technology and engineering aspects. This is in line with the statements; students can express natural objects, situations or everyday events in the form of mathematical models well [15], the student's ability to analyze and write mathematical symbols is in the high category [16], and the success of students in converting mathematical problems become mathematical models [17].

Students can visualize a problem in graph form with mathematical problems related to the mathematics aspect in the visual communication category. To make a graph, the students first determine the point of intersection of the $x$-axis and the $y$-axis in each known equation in the problem. Furthermore, the graph is made using the intersection component obtained at the coordinates of the $x$-axis and $y$-axis, but in finding the intersection point, the image is not perfect because students pay less attention to the shape of the graph that has been made and in determining the coordinate points students do not keep a consistent distance at each point.. This is what makes students not fully able to visualize the situation given the problem in reflecting it in graphic form. They can only apply some information to draw graphs [18] and describe problem situations in the geometric form [19].

Students can solve the problem well in the category of text communication that uses its language based on a given situation or mathematical model related to the scientific aspect of the problem. This means that students understand the situation based on story questions to get information in solving a problem. Thus, students can change the given situation into a mathematical model that belongs to the category of symbolic communication and interpret the steps to answer the solution method, which is then used in finding the desired result using their language. Students chose the substitution method to solve problems with students changing one of the equations made to get the value of $x$ and then substituting the value of $x$ into the other equation to get the value of $y$. Based on the $x$ and $y$ values obtained, students can determine how much chicken meat is needed for tiger and lion tails to get conclusions from the answers correctly based on mathematical problems related to aspects of science. This is relevant to the statement that students can write answers using their language and complete them thoroughly [20]. The strategy of solving a problem used is coherent and systematic [21]. This is based on the fact that students who have good self-confidence can convey mathematical ideas either in writing or orally so that in solving some problems, they can choose the correct method to use [22].

\section{CONCLUSION}

This research concluded that there are three categories of student communication in solving STEM problems. First, students in the symbolic communication category had the characteristics of students who could state real situations or objects given in language or mathematical symbols. Second, students in the visual communication category had the 
characteristics of students who could express the situation of mathematical ideas in pictures, graphs, tables or other forms. Third, the text communication category had the characteristics of students could express situations, pictures, or natural forms into language or mathematical symbols.

The research results could be used as a theoretical guide in mathematical communication research. Further research can focus on students' mathematical communication characteristics based on the timing aspect, which highlights when problem-solvers communication skills emerge in solving problems.

\section{ACKNOWNLEDGMENTS}

The author would like to thank SMP Negeri 2 Belitang III, mathematic teachers, and all students who have been willing to become research subjects.

\section{REFERENCES}

[1] W. Srikoom, "Science teachers' professional development program for designing stem integrated lesson plan," J. Phys. Conf. Ser., vol. 1957, no. 1, p. 012040, 2021

[2] N. Milaturrahmah, Mardiyana, and I. Pramudya, "Science, technology, engineering, mathematics (STEM) as mathematics learning approach in 21 st century," AIP Conf. Proc., vol. 1868, no. August, 2017.

[3] M. Aufa, S. Saragih, and A. Minarni, "Development of Learning Devices through Problem Based Learning Model Based on the Context of Aceh Cultural to Improve Mathematical Communication Skills and Social Skills of SMPN 1 Muara Batu Students," J. Educ. Pract., vol. 7, no. 24, pp. 232-248, 2016.

[4] D. Yusra and S. Saragih, "The Profile of Communication Mathematics and Students' Motivation by Joyful Learning-based Learning Context Malay Culture," Br. J. Educ. Soc. Behav. Sci., vol. 15, no. 4, pp. 1-16, 2016.

[5] W. Is, “Pssm,” J. Equine Vet. Sci., vol. 18, no. 11, p. 719, 1998.

[6] N. D. Putri and E. Musdi, "Analysis of students Initial mathematical communication skills in mathematics learning," J. Phys. Conf. Ser., vol. 1554, no. 1, p. 012064, 2020.

[7] H. Hendriana, E. E. Rohaeti, and U. Sumarmo, "Hard Skils dan Soft Skill Matematik Siswa."
Refika Aditama, Bandung, p. 59, 2019.

[8] Zulhelmi and Anwar, "Mathematical communication skills in solving block and cube problems," J. Phys. Conf. Ser., vol. 1882, no. 1, p. 012065, 2021.

[9] N. Fitzallen, "STEM Education: What Does Mathematics Have To Offer ?," Proc. 38th Annu. Conf. Math. Educ. Res. Gr. Australas., no. June 2015, pp. 237-244, 2015.

[10] M. N. Hassan, A. H. Abdullah, N. Ismail, S. Norbazilah, A. Suhud, and M. H. Hamzah, "Mathematics curriculum framework for early childhood education based on science, technology, engineering and mathematics (STEM)," Int. Electron. J. Math. Educ., vol. 14, no. 1, pp. 15-31, 2019.

[11] A. Veloo, R. Md-Ali, and S. Chairany, "Using cooperative teams-game-tournament in 11 religious school to improve mathematics understanding and communication," Malaysian J. Learn. Instr., vol. 13, no. 2, pp. 97-123, 2016.

[12] C. Olteanu and L. Olteanu, "Enhancing mathematics communication using critical aspects and dimensions of variation," Int. J. Math. Educ. Sci. Technol., vol. 44, no. 4, pp. 513-522, 2013

[13] Budiyono, Pengantar Metodologi Penelitian Pendidikan. Surakarta: UNS Press, 2017.

[14] C. Sa'dijah, M. N. Kholid, E. Hidayanto, and H. Permadi, "Are there Differences in Reflective Thinking Between Male and Female Prospective Mathematics Teachers?," Proc. 7th Int. Conf. Res. Implementation, Educ. Math. Sci. (ICRIEMS 2020), vol. 528, no. Icriems 2020, pp. 344-351, 2021.

[15] M. Anwar Rivai, Mardiyana, and I. Slamet, "An Analysis of Mathematical Communication Ability on Solving Open Ended Problems in Linier Equation System with Two Variables," J. Phys. Conf. Ser., vol. 1776, no. 1, p. 012015, 2021.

[16] A. C. Septiana, T. A. Kusmayati, and L. Fitriana, "Mathematical communication skill of senior high school students based on their personality types," J. Phys. Conf. Ser., vol. 1108, no. 1, p. 012027, 2018.

[17] N. Kholidah and A. Qohar, "Students' mathematical communication in teams games tournaments (TGT) learning model on trigonometry topic," J. Phys. Conf. Ser., vol. 1806, no. 1, p. 012110, 2021. 
[18] L. F. Utami, I. Pramudya, and I. Slamet, 'Students' Mathematical Communication Skills in Terms of Concrete and Abstract Sequential Thinking Styles," Al-Jabar J. Pendidik. Mat., vol. 11, no. 2, pp. 371-381, 2020.

[19] E. Rohmanawati, T. A. Kusmayadi, and L. Fitriana, 'Student's mathematical communication ability based on Kolb's learning styles of assimilator and accommodator type," J. Phys. Conf. Ser., vol. 1806, no. 1, p. 012091, 2021.

[20] N. Gardenia, T. Herman, D. Juandi, T. Dahlan, and T. Kandaga, "Analysis of mathematical communication skills of class 8 students on two-variable linear equation systems (SPLDV) concept," J. Phys. Conf. Ser., vol. 1806, no. 1, p. 012073, 2021.

[21] E. Rohmanawati, T. A. Kusmayadi, and L. Fitriana, "Analysis of Students' Mathematical Communication Ability Based on Kolb's Learning Styles of Converger and Diverger Type," IOP Conf. Ser. Earth Environ. Sci., vol. 1808, no. 1, p. 012050, 2021.

[22] Y. S. Achir, B. Usodo, and R. Retiawan, "Analisis Kemampuan Komunikasi Matematis Siswa Dalam Pemecahan Masalah Matematika Pada Materi Sistem Persamaan Linear Dua Variabel (Spldv) Ditinjau Dari Gaya Kognitif," Paedagogia, vol. 20, no. 1, pp. 78-87, 2017. 